\title{
Penatalayanan Ibadah Terbatas Pada Masa Pandemi Covid-19
}

\author{
Erman Sepniagus Saragih \\ Institut Agama Kristen Negeri Tarutung \\ ermansaragih9@gmail.com
}

\begin{abstract}
This article has an idea about the arrangement of limited worship (individuals) during the covid-19 pandemic. In this article, the functions of obedience theology, the construction of koinonia, and the liturgy of perichoresis are sub-discussed. The lens of discussion about theology during the Covid-19 pandemic. Empirically, worship at home is a massive and proactive solution. The capacity of worship at home is always carried out in a hierarchical liturgical pattern. Koinonia as a spirit relation of communal communion is constructed as a model for the church of individual koinonia. The method used is a literature study, specifically content analysis with the principle of systematic literature review. The conclusion that I convey is first, obedience theology as the basis of Christian spiritual ethics. Second, the early church fellowship pattern emphasized dynamic power by the apostles so that they were able to endure and overcome obstacles. Third, proactive fellowship becomes a common model to survive and start thinking about the future of the church. Fourth, individual worship liturgies can consider the principle of the perichoresis relation to delay the hierarchical pattern of worship.
\end{abstract}

Keywords: stewardship; covid-19; koinonia proflektif; perikoresis

\begin{abstract}
Abstrak
Artikel ini menyoal tentang penatalayanan ibadah terbatas (di rumah) pada masa pandemi covid19. Pada artikel ini fungsi teologi ketaatan, konstruksi koinonia, dan liturgi perikoreisis menjadi sub pembahasan. Lensa pembahasan seputar teologi di masa pandemi Covid-19. Secara empiris, ibadah di rumah menjadi solusi masif dan bersifat proflektif. Kapasitas ibadah di rumah selalu dilakukan dalam pola liturgi hierarkis. Koinonia sebagai relasi spirit persekutuan komunal dikonstruksi menjadi model menggereja koinonia individual. Metode yang dilakukan menggunakan studi literatur secara khusus analysis content dengan prinsip tinjuan literatur secara sistematis. Kesimpulan yang saya sampaikan adalah pertama, teologi ketaatan sebagai basis etis spritual ibadah terbatas. Kedua, pola persekutuan gereja mula-mula menekankan kuasa dinamis oleh para rasul sehingga mampu bertahan dan melampaui hambatan. Ketiga, persekutuan Proflektif menjadi model bersama untuk bertahan dan mulai memikirkan masa depan gereja. Keempat, liturgi ibadah individual dapat mempertimbangkan prinsip relasi perikoresis untuk menunda hierarkisasi pola ibadah.
\end{abstract}

Kata Kunci: penatalayanan; covid-19; koinonia proflektif; perikoresis

\section{Pendahuluan}

Pelaksanaan ibadah terbatas (individual) memunculkan persoalan multidimensi bagi keluarga di samping masalah yang timbul akibat pandemi Covid-19. Sebagian majelis gereja hanya memberikan tata ibadah setiap Minggunya kepada jemaat. Namun, ketika melaksanakan ibadah di rumah siapa yang layak memimpin ibadah (sebagai pendetapenatua) di rumah? Bagaimana kekhusyukan ibadah di rumah sebagai kebiasaan relasi 
dinamis antara orang tua dan anak-anak? Beberapa akademisi telah memberikan argumentasinya terkait perilaku ibadah pada masa pandemi Covid-19 namun, belum ada kajian yang menyentuh tentang penatalayanan ibadah terbatas (dirumah, online, dan individual). Dengan demikian, artikel ini memberikan perspektif khusus tentang penatalayan ibadah terbatas (individual) jemaat.

Pelaksanaan ibadah pada masa pandemi Covid-19 telah menstimulus pelayanan kelompok peribadatan berpindah dari visual ke media online (Berutu \& Evan Siahaan, 2020). Beberapa gereja diantarnya menggunakan media zoom, youtube, dan google meet tetapi, beberapa gereja tetap melakukan perseketuan dengan cara membatasi jumlah peserta ibadah. Demikian juga, Onisimus Langfan mengemukakan bahwa ibadah yang dilakukan secara online sebenarnya hanya bersifat tentatif dan reaksi spontanitas tanggap gereja untuk menyesuaikan diri dengan dampak wabah covid-19. Langfan juga menandaskan bahwa tanggapan jemaat terhadap ibadah online sangat signifikan tidak menunjukkan kesungguhan dan kekhusyukan ketika mengikuti ibadah di rumah (Langfan, 2021). Dengan demikian, bagi Langfan ibadah online kurang efektif karena faktor kebiasaan beribadah dengan cara persekutuan (komunal) telah membudaya dalam gereja sehingga, pola ibadah masih dirasa asing dan janggal. Demikian juga Roedy Silitonga mengatakan bahwa hal mendasar dan menjadi keutamaan bagi jemaat dalam melakukan ibadah di rumah ialah sikap kesungguhan, kekhusyukan sebab, ibadah ditujukan kepada Allah Tritunggal Maha Kudus (Silitonga, 2020). Silitonga menandaskan bahwa ibadah yang sungguh-sungguh identik dengan ibadah yang sejati (Roma 12:1). Ibadah yang khusyuk pasti mendekatkan orang percaya bersama-sama dengan Tuhan sebagai respon syukur (Zega, 2020). Artinya, kesungguhan seseorang memberikan rasa syukurnya diukur dari sikap jemaat dalam melaksanakan peribadahan.

Hakikat ibadah bukan sekadar perjumpaan Allah dengan jemaat secara komunal di ruang sakral namun, lebih kepada pernyataan spritualitas personal diruang kosmik. Pelaksanaan ibadah tidak dibatasi pada sikap khusyuk dalam ruang sakral saja tetapi totalitas dalam ruang profan dan sakral. Perjumpaan dengan Allah hadir tidak dibatasi oleh ruang dan waktu. Sekalipun sikap kekhusyukan menjadi indikator penting dalam pelaksanaan ibadah, akan tetapi prinsip relasi perikoresis telah membuktikan kasih Bapa melalui Yesus membuka seluas-luasnya bentuk ibadah transformatif. Sebab, taat pada perintah Yesus (hukum baru) dalam ruang sakral dan profan sebagai bukti kita mengasihi Allah yang Trinitatis. Dengan demikian, prinsip apakah yang perlu diperhatikan dalam penatalayanan ibadah terbatas (individual-di rumah) dimasa pandemi Covid-19? Dengan demikian, artikel ini bertujuan memaparkan prinsip teologi ketaatan, prinsip persekutuan jemaat mula-mula, koinonia proflektif, dan liturgi hierarkis-perikoresis sebagai sebuah tawaran teologis dalam penatalayanan ibadah terbatas.

\section{Metode}

Pada artikel ini fokus yang dibahas adalah teologi ketaatan, koinonia prokplektif, dan liturgi perikloresis sebagai prinsip dasar ibadah di rumah. Dengan berkembangnya varian baru virus Covid-19 ibadah di rumah dan ibadah berbasis online menjadi alternatif 
maka, prinsip penatalayanan ibadah terbatas perlu dipahami bersama. Penelitian dalam artikel ini dilakukan dengan cara studi literatur dengan prinsip analysis content secara sistematis (Systematik Literatur Riviwer). Data utama (primer) diacu berdasarkan literatur yang kredibel baik dalam bentuk buku dan jurnal online dan cetak. Kredibel dalam pengertian buku-jurnal sering dijadikan pegangan dan dikutif oleh ilmuan-teolog yang melakukan kajian topik yang sama. Data sekunder bersumber dari artikel dan publish dalam aras pembahasan jemaat lokal. Sumber data diperoleh dari literatur buku dan artikel yang bereputasi secara nasional dan internasional. Kriteria data yang dipilih berdasarkan kesamaan topik penelitian dan tema-tema yang dikaji. Dalam pengumpulan data selalu membuat catatan (koding data). Analisis data dan konfirmatori data juga dilakukan untuk memeroleh data jenuh dan sahih. Konfirmasi dilakukan kepada buku utama atas artikel penulis jurnal nasional dan internasional. Analisis data yang digunakan secara deduktif. Setiap buku dan artikel jurnal dibaca secara metodologis (literatur review) dan dianalisis berdasarkan argumentasi kunci ide pokok pembahasan, memahami temuan, dan membuat kesimpulan. Semua data dinarasikan dengan prinsip dialektis (dialog tesis-antitesis-sintesis) dan membuat argumentasi logis berdasarkan reduksi data dalam artikel ini. Pada akhirnya kesimpulan dan saran penelitian lanjutan disampaikan.

\section{Hasil dan Pembahasan}

Penatalayanan dalam Alkitab mencakup hal tanggungjawab seseorang dalam mengurus, mengepalai, mengatur dan mengerjakan segala kegiatan yang dipercayakan kepadanya (bnd. Kej. 43:19, 44:4) dengan tujuan sebagai bukti pengabdian kepada tuan dan pemiliknya di atas masalah yang ada (1 Kor. 4:1,2, Tit. 1:7, 1 Ptr. 4:10). Penatalayanan adalah tanggungjawab manusia dihadapan Allah untuk hidup dalam kehendak Allah sebagaimana tersimpul dalam diri Yesus (Yoh. 7:16-18, 6:37-40, 12:49-50).

Penalayanan ibadah merupakan bagian dari liturgi. Liturgi sebagai kekuatan (akte) legalitas atas kegiatan pelayanan jasa umum. Secara etimologi kata liturgi dalam bahasa Yunani adalah leitourgia. Liturgi terdiri dari dua kata, yaitu "leitos" orangorang/publik dan "ergon" karya, sehingga liturgi adalah ibadah atas karya mistis Allah melalui Yesus Kristus bersama dengan orang percaya dengan dan di dalam ikatan Roh Kudus (Emanuel, 2011). Pada teks Septuaginta (LXX) kata liturgi menghunjuk pada praktik pelayanan di Bait Suci (Kel. 38:7; Ibr. 8:6). Kekristenan menyebut pelayanan gereja kepada jemaat publik dalam bentuk ritus, doa, seremoni. Konteks gereja di Barat lebih pada sakramen dan gereja di Timur lebih pada upaca ekharisti. Sekaitan dengan beberapa definisi tersebut dapat disimpulkan bahwa liturgi berkaitan erat dengan praktik bahwa Allah melayani umatNya dalam ruang ksomik. Dengan demikian penatalayanan liturgi ibadah terbatas (individu) bukan sesuatu yang tabu bagi Allah sebab, keberadaanNya tidak bisa dibatasi keadaan ruang dan waktu.

Berdasarkan hasil analisis buku dan artikel jurnal, penatalayanan ibadah di rumah pada masa pandemi dilaksanakan dengan memperhatikan prinsip taat protokol kesehatan, prinsip spritualitas iman jemaat mula-mula, prinsip koinonia Proflektif, dan 
prinsip ibadah perikoresis. Beberapa hasil kajian tentang ibadah di rumah dalam bentuk buku dan jurnal telah memberikan perspektifnya masing-masing. Misalnya dalam artikel Saragih dan Hasugian mengemukakan bahwa kasih mula-mula, kesabaran yang teruji, penyediaan asupan gizi, dan berbagi kasih sebagai basis pola asuh orang tua di masa pandemi dalam menata keluarga (A. Saragih \& Hasugian, 2020). Namun, fungsi orang tua tidak sekadar mengasuh anak-anak sebagaimana biasanya. Orang tua memiliki tanggungjawab baru yaitu menjadi pengganti peran pemimpin ibadah di gereja. Apakah orang tua sudah cukup mumpuni untuk menjadi imam dan sekaligus sahabat bagi anggota keluarga?

Dalam beberapa tradisi gereja misalnya gereja suku Batak, pola ibadah hierarkis menjadi sebuah tradisi. Mereka yang telah berusia dan dianggap tualah paling pantas dan berpengalaman dalam memimpin ibadah. Menurut hemat saya, konteks situasi saat ini semua pola kebiasaan liturgi harus mengarah fleksibilitas dan transformasi sosial. Sebab, jika budaya patriakal menjadi pedoman dalam melaksanakan ibadah terbatas maka perlu dipertimbangkan bahwa tidak semua kaum bapak mau berperan sebagai pemimpin ibadah (liturgos). Saya menyarankan perspektif spritual komunal ke philiarki sebagai basis ibadah terbatas dan sikap bertahan dan merengkuh virus Covid-19. Spritualitas philiarkis bertolak belakang dengan hierarkis, kuriarkis, dan duliarkis (Adiprasetya \& Sasongko, 2019). Sebagaimana Virgil Michel, O.S.B (1890-1930) mengatakatan bahwa kehidupan manusia baiknya bergantung pada atau ditetapkan pada nilai dan makna otoritas tertinggi dari kehidupan. Sebab, Yesus jelas menegaskan bahwa keberadaan-Nya telah menyahabati segala alam semesta sebagai Alllah yang Trinitatis. Inilah dasar spirit persabatan Yesus kepada murid-murid. Sekalipun begitu sulit untuk dipahami dalam kerangka logika namun untuk mencapai spritualitas menjadi sahabat menjadi solusi penting ditekankan dalam menjalankan ibadah di rumah pada masa pandemi covid-19. Alexander Schmemann dalam artikelnya, "Worship In A Secular Age" mengatakan bahwa hubungan manusia dengan alam semesta tersirat di dalam pengertian peribadahan itu sendiri. Ibadah merupakan realitas berdimensi kosmik, sejarah, dan eskatologis bukan hanya sekadar berkutat pada kesalehan tetapi dari pandangan dunia yang mencakup semua. Dengan demikian, ibadah bukan hanya sekadar upacara seremonial di ruang sakral dan kegiatan proyek yang terlepas dari realitas tetapi lebih kompleks berdimensi kosmik.

\section{Teologi Ketaatan}

Ketaatan Yesus dengan cara mengosongkan diri (kenosis) dan mewujud dalam daging manusia (inkarnasi) bahkan rela mati tersalib adalah sebagai basis teologi ketaatan. Dalam penerapan praktis gereja, kenosis dan inkarnasi merupakan kemampuan untuk menahan diri atas kehendak pribadi demi kebebasan bersama menikmati hadirat pelayanan Allah.

Orang percaya (diaklesia) taat terhadap protokol kesehatan sebagai karakter khas kristiani dalam ruang publik. Sebab, dengan taat, Abraham disebut sebagai bapak orang beriman. Para rasul menerima kuasa dan pencurahan Roh Kudus adalah akibat dari 
ketaatan mereka. Sebaliknya, Yunus masuk dalam perut ikan karena ketidaktaatannya pada perintah Allah (Yun. 1:7; 2:1). Iman yang mewujud dalam perilaku taat menjadi harapan dan sikap Kristus yang diwujudkan sebagai langkah untuk merayakan hidup bersama pandemi Covid-19.

Protokol kesehatan dan sering diakronimkan sebagai "prokes" mengandung legalitas hukum formal. Presiden Republik Indonesia Joko Widodo pada bulan Juli tahun 2021 menegaskan kepada seluruh rakyat Indonesia untuk patuh pada prokes, menerima vaksinasi, menerapkan $5 \mathrm{M}$, dan melakukan kegiatan testing, tracing, isolasi, dan treatment secara masif (Media, 2021 Diakses tanggal 4 Agustus 2021).

Gereja mulai merengkuh realitas pandemi Covid-19. Gereja telah menyadari risiko yang ditimbulkan jika ibadah dilakukan dalam bentuk kerumunan. Indikasinya, gereja sedang menunda ibadah komunal dan menerapkan ibadah individual (terbatas) sebagai langkah tentatif-spontan. Majelis gereja berketetapan hati untuk membatasi jumlah jemaat beribadah dalam ruangan gereja sesuai dengan peraturan protokol kesehatan. Ibadah Minggu diselenggarakan dalam beberapa sesi. Dengan demikian gereja menampilkan bukti ketaatan dan keikutsertaanya dalam penerapan PPKM demi menjamin keselamatan jemaatnya.

Terkait teologi ketaatan, Roger Morhlang dalam tulisannya "Matthew and Paul: A Comparison of Ethical Perspective" mengemukakan hasil analisisnya tentang Injil dan Hukum dengan menempatkan Injil Matius secara tepat dalam latar belakang Yahudi. Ia mengungkapkan bahwa etika kehidupan pada abad pertama bagi orang Yahudi dipahami sebagian besar dalam hal ketaatan pada Hukum Musa. Morhlang juga menegaskan bahwa dalam sistem etika apa pun selalu didasarkan pada pertimbangan hukum, otoritas, kepatuhan, dan penilaian. Pertimbangan tersebut merupakan konsep kunci dalam keseluruhan struktur dan sangat mewarnai pandangan hidup orang Yahudi. Kemudian, Morhlang menyimpulkan bahwa Matius menduga dengan kuat bahwa seluruh hukum itu sah dan berwibawa bagi komunitas Kristen (Mohrlang, 1984). Komunitas Matius tidak boleh melupakan hukum, sebab taat hukum sebagai ukuran religiositas mereka. Dengan demikian ketaatan pada prokes dan melakukan ibadah terbatas sebagai aktualisasi iman pengikut Kristus.

\section{Persekutuan Komunitas Kristen Mula-mula}

Progres pelaksanaan ibadah menurut umat Perjanjian Lama merupakan iman dimana Allah hadir memberi keselamatan melalui wadah tempat kudus seperti Bait Suci. Kehadiran Allah bukan sebatas simbol tetapi adanya kegiatan menata, mengorganisasi, dan memberi pertumbuhan. Ibadah di dalam Perjanjian Baru lebih menekankan kehadiran Allah yang tidak dibatasi oleh hal-hal normatif seperti tata ibadah (liturgi), bangunan, dan sarana ibadah (Lukuhay, 2020). Dengan demikian ibadah termaktud dalam pertemuan unsur keillahian dan kemanusiaan sejati dalam Yesus. Karya Allah ini disebut "koinonia" sebagai persekutuan dan penciptaan realitasnya. Tindakan Allah dalam bentuk persekutuan di dunia merupakan ide murni politik Allah, tindakan mesianis Tuhan dalam mengatur dan menjabarkan dunia sebagai komunitas hidup. 
Dalam situasi pandemi saat ini, praktik ibadah di rumah cenderung digambarkan kearah ratapan, keluhan, dan ketidaknyamanan atas situasi bencana yang terjadi (Hutahaean et al., 2020). Penatalayanan ibadah yang ditawarkan cenderung berimplikasi pada teks Alkitab dan berangkat dari lensa case locus pribadi masing-masing. Pelayanan ibadah berbasis teknologi digital menjadi bagian dari pola ibadah tentatif baik di daerah kota dan pedesaan. Namun, kendala yang terjadi adalah beberapa gereja telah eksis dalam ibadah berbasis digital atas dasar tujuan penjangkauan jemaat modern. Setiap inovasi bentuk ibadah baik adanya, hanya saja perlu dilakukan monitoring dan evaluasi terkait dampaknya bagi pendewasaan spritualitas jemaat.

Pada konteks ibadah mula-mula di dalam Kisah Para Rasul, persekutuan di rumahrumah juga merupakan hal baru bagi mereka. Namun, ada kesehatian, keseragaman, dan saling tolong-menolong. Komunitas kekritenan mula-mula melakukan ibadah di rumah dan juga melakukan persekutuan bersama komunitas Yudaisme di Sinagoge (E. S. Saragih, 2019). Pola ibadah yang mereka lakukan sama, hanya saja berbasis iman dalam bentuk ketaatan yang mengacu kepada ajaran Yesus. Pada masa kekristenan mula-mula, tantangan dalam peribadatan mencakup banyak hal termasuk perbedaan liturgi, bahan ibadah, ajaran, dan pemahaman tentang keselamatan. Perbedaan doktrin kepercayaan semakin muncul ke permukaan publik sehingga komunitas pengikut Kristus terpisah dan dipisahkan dari Sinagoge (Sim, 1998a, p. 142). Pada masa kini, tantangan utama adalah pandemi virus Covid-19 serta bencana yang diakibatkannya. Dampak utama yang terlihat adalah terpisahnya pola ibadah komunal menjadi individual (terbatas), ibadah di gedung gereja menjadi ibadah di rumah.

Pada masa persekutuan jemaat mula-mula, mereka mendapat tantangan secara internal dan eksternal. Secara internal tantangan berada pada siapa yang layak dan berhak menjadi pemimpin ibadah dan apa yang diajarkan. Sebab, dalam Kisah Para Rasul menggambarkan bahwa komunitas mereka secara menyeluruh mendapat pencurahan Roh Kudus. Hal itu diidentikkan dengan kemampuan mereka mengucapkan bahasa milik orang lain ketika memimpin dan mengajarkan Injil. Secara eksternal tantangan yang mereka hadapi berasal dari komunitas Yudaisme dan pemerintah Romawi. Kelompok agama Yahudi ini menganggap jemaat kristen mula-mula sebagai ajaran sesat, pembelot, dan saingan kuat secara politik (Sim, 1998b, p. 154). Demikian juga, secara politis, Romawi pada abad pertama sampai pada perintahan Konstantinus (tahun 312) secara terprogram melakukan pengejaran dan penyiksaan bagi jemaat Kristen yang tidak mau menyembah Kaisar sebagai tuhan dan taat pajak. Pengalaman dan iman jemaat mulamula yang dikuatkan oleh Roh Kudus lah yang membuat mereka tetap setia dan berani menanggung martir. Situasi dan kondisi ini mengidentikan persekutuan proplektif. Mereka setia dalam penderitaan karena adalah pengharapan akan masa yang lebih baik yang disediakan Tuhan.

Pada awal abad pertama masehi, persekutuan dilakukan di rumah-rumah dan dipimpin oleh para rasul. Rumah merupakan unit sosial, ekonomi, dan religious sehingga pada masa para rasul kegiatan ibadah dan pengajaran rohani mengenai iman kekristenan berawal dari refleksi di rumah. Dalam tradisi Israel, rumah memiliki tempat khusus yaitu 
bagian atas sebagai tempat peribadahan kepada Allah (bnd. Mrk. 2:4). Ciri khas pemimpin ibadah bagi suku Israel adalah kepala keluarga (laki-laki) yang menjadi imam. Kaum perempuan bertanggung jawab penuh dalam mengelola rumah tangga dan anak-anak di rumah (hierarkis) (Fransiskus dkk, 2021). Pada masa pandemi ini, orang tua berperan ganda baik dalam hal pembelajaran, menjadi guru, dan menjadi sahabat bermain bagi anak-anak. Dengan pendobelan porsi tanggung jawab orang tua, pola pengasuhan dalam rumah tangga berbasis pada kasih mula-mula antar keluarga kembali ditawarkan (A. Saragih \& Hasugian, 2020). Dengan demikian, pengelolaan ibadah terbatas dilakukan berdasarkan prinsip kasih persabatan sebagaimana Yesus menyebut murid-murid sebagai sahabatNya.

Tipikal persekutuan jemaat mula-mula menjadi evaluasi prototipe bagi ibadah di rumah yang terbatas di masa pandemi Covid-19. Berdasarkan indikator tantangan dan kesulitan yang terjadi pada masa itu tentu kualitas dan kuantitasnya lebih berat pada jemaat mula-mula. Namun, kualitas iman yang ditampilkan mereka justru misioner. Iman kokoh para rasul memberikan gambar dinamisasi dan spirit perkembangan pengikut Kristus. Iman yang andal menghasilkan kuantitas jemaat. Iman dengan kualitas dinamis mampu menciptakan penatalayanan transformatif di era pandemi Covid-19. Kuasa dinamis mampu mengelola keterbatasan fasilitas berbasis teknologi digital dan teknologi informasi secara tentatif menjadi wadah persektuan ibadah. Teknologi informasi dapat ditata sebagai media koinonia dalam bentuk interaktif dalam kondisi keterbatasan. Walaupun dalam keterbatasan terdapat tantangan tetapi, ketaatan proflektif menjadi keutamaan sebab sudah teruji dan terbukti lewat masa para rasul.

\section{Koinonia Proflektif}

Proflektif berasal dari kata pro dan reflektif. Reflektif berarti tindakan di luar kemauan-kehendak pribadi manusia. Gerakan ini tidak direncanakan dan biasanya bersifat spontanitas. Ibadah Proflektif menurut Joas Adiprasetya dalam orasi ilmiahnya ialah gereja yang menghasrati masa depan walaupun di depan belum begitu terang masih kabut dan gelap. Gereja tidak mampu menerawang terlalu jauh masa depan. Ciri khas ibadah ini adalah unlearning (pertobatan), lament (ratapan), virtues (kebajikan). Pada masa pandemi gereja jangan terlalu cepat dan buru-buru dalam menentukan sikap. Masa depan gereja setelah postpandemi belum bisa diterawang. Di depan masih terlihat kabut dan gelap. Joas Adiprasetya dalam orasi ilmiahnya menyampaikan masa ini sebagai momentum tepat bagi gereja untuk bertobat, meratap, dan memprioritaskan keutamaan.

Wowor menyampaikankan dalam artikelnya bahwa persekutuan (koinonia) tidak hanya terdapat dalam gedung gereja sebab persekutuan gereja tidak hanya untuk baginya sendiri. Koinonia sebagai kata kerja yaitu bersekutu, berbagi, berpartisipasi, mengambil bagian, dan bertindak bersama sebagai persekutuan dengan partisipasi intim. Semua bagian ini mengarah pada relasi dengan Tuhan dan sesama (Wowor, 2015). Dengan demikian otentisitas gereja ditemukan dalam persekutuan, hubungan, dan perjumpaan (Höring, 2013). Persekutuan hadir sebagai semangat gereja mula-mula dalam komunitasnya. Idealnya, semua bagian koinonia diwujudkan tanpa dibatasi oleh situasi 
dan bencana apapun. Penegasan fungsi koinonia bukan berarti sebagai bentuk propokasi tanpa beralasan teologis, namun rekonstruksi ulang bentuk persekutuan dalam situasi wabah Covid-19.

Dalam konteks gereja-gereja di Indonesia konsep koinonia sebagai fungsi gereja menggambarkan hakikat dari komunitas atau persekutuan yang sejati. Dalam bahasa Yunani disebut koinonia sedangkan dalam diksi Aram dan Ibrani yaitu yahad (kesatuan, persatuan) yang dipakai dalam kitab komunitas Qumran. Menurut World Council of Churches, koinonia mengandung makna menjalin persekutuan untuk memiliki hubungan yang mutual di hadapan Tuhan melalui aktivitas berpartisipasi, berbagi dan bersekutu dengan orang lain melekat dalam diri manusia (Book, 2013).

Koinonia adalah kriteria dasar untuk tindakan dalam proses mengikut Yesus. Pencarian dan penawaran koinonia adalah dasar dari semua kegiatan dan karakteristik utama dari semua tugas gerejawi, sehingga dapat disebut sedikit artifisia (buatan). Koinonia yang dipahami sebagai suatu hubungan, menjadi kriteria internal dari tiga dimensi fundamental gerejawi. Sebuah gambaran yang diberikan oleh H.G. Behringer mengatakan bahwa kesatuan manusia dalam empat yang terdiri dari tubuh, jiwa, pikiran dan hati (Höring, 2013). Tubuh yang bersekutu dibatasi pada komunitas keluarga, sedangkan jiwa, pikiran, dan hati tidak dapat di batasi oleh apapun.

Sekalipun ibadah dipahami dan tergambar dalam persekutuan komunitas, akan tetapi makna koinonia tidak dibatasi pada jumlah peserta dan tempat melaksanakannya. Persekutuan Proflektif pada hakikatnya adalah persekutuan yang melampaui doktrin liturgi, tempat, dan struktur gereja. Koinonia Proflektif merupakan refleksi persekutuan atas situasi baru dan tanpa direncanakan. Menurut saya model persekutuan reflektif relevan dalam situasi ibadah di rumah. Allah membangun keluarga sebagai intitusi pertama. Melalui keluarga, persekutuan menjadi reflektif dan dinamis.

\section{Liturgi Hierarkis ke Perikoresis}

Perichoresis berasal dari bahasa Yunani dan memiliki makna berdiam bersama. Tupamahu berpendapat bahwa perichoresis akan membantu orang Kristen merumuskan model yang baik untuk keterlibatan penuh kasih dengan yang lain (Tupamahu, 2013). Dengan demikian berdiam bersama bukan berarti satu agama, satu tempat, dan satu liturgi. Sama seperti yang dikemukakan Jurgen Moltman bahwa persekutuan perichoresis merupakan persekutuan Trinitatis yaitu Allah, Anak, dan Roh Kudus tidak menyatu sehakikat namun saling terhubung dalam ikatan Trinitatis (Meeks, 2000, p. 114). Tantangan Moltman seputar belbagai kepercayaan, seakan-akan berbeda dan menjadi sekat pemisah. Namun, pada saat ini virus Corona telah membangun sekat bukan lagi karena perbedaan pandangan keagamaan. Satu keluarga sekalipun menjadi saling curiga dan membatasi diri dalam interaksi kehidupan sehari-hari ketika terpapar virus.

Yesus memperbaharui koinonia horizontal dengan praktik tindakanNya. Dasar dari pembaharuan ini adalah Allah telah memperbaharui terlebih dahulu koinonia vertical. Evan Siahaan mengatakan bahwa sejatinya gereja menampilkan spiritualitas perikoresis dan berdaya dinamis dalam persekutuan trinitatis. Persekutuan perikoresis 
merupakan prinsip relasi atau persekutuan Allah Trinitas yang menghadirkan Bapa, Anak, dan Roh Kudus. Prinsip pertama perikoresis adalah persekutuan Trinitatis yang tak berbaur dan tak tercampur namun saling terhubung (Siahaan, 2021). Jadi, Yesus memberikan secara otoritatif kepada individu kesempatan untuk memulai yang liturgi baru. Keputusan untuk memulai liturgi baru mengarah pada cara bertindak yang baru. Etika dasar dari liturgi baru mengacu pada apa yang ditampilkan Yesus memungkinkan bentuk keberadaan baru, 'kamu memiliki hidup baru (keselamatan dan janji keselamatan), jadi bertindaklah sesuai dengan itu (Höring, 2013).

\section{Implikasi}

Jika Yesus taat pada Bapa sampai mati, maka gereja sebagai wujud kerajaan Allah harus menampilkan ketaatan sebagai habitus. Azas ketaatan Yesus adalah kasih kepada dunia dan isinya. Jika kita tidak taat pada prokes, bisa jadi kita miskin kasih. Ketaatan tidak hanya berbicara manfaat eskatologi atau masuk surga atau tidak, namun ketaatan harus tampil sebagai wujud garam dan terang ditengah-tengah masyarakat. Bukti kita mengasihi Allah adalah kita mengasihi sesama manusia. Tidak egosentris. Mengutamakan kemaslahatan kehidupan bersama. Gereja mendukung taat prokes dalam diakonianya. Gereja taat prokes dalam koinonianya. Ketaatan melakukan prokes sebagai spritualitas marturia.

Dalam persekutuan komunitas Kristen mula-mula tidak terlepas dari tantangan dan hambatan. Tantangan komunitas itu juga tidak sekadar mempertaruhkan nyawa namun dampak bagi keturunan keluarga. Persekutuan yang dibangun adalah berawal dari persekutuan komunitas di rumah-rumah. Sebelumnya Sinagoge sebagai media persekutuan komunal secara luas. Dari komunitas rumah menjadi komunitas rasul dengan jemaatnya. Komunitas yang dibangun para rasul terjadi atas dinamisasi-Roh Kudus. Para rasul yakin bahwa relasi dengan kuasa Roh Kudus memampukan mereka dalam melewati hambatan dan permasalahan. Kuasa Roh Kudus tidak tunduk pada kuasa apapun, namun tidak mengubah kemahakasihan Allah. Tidak menjadi kesombongan kasih Allah, namun memiliki kuasa yang memang melampaui kuasa apapun.

Koinonia proflektif sebagai indikasi peribadatan pada masa pandemi. Tidak ada kemahatahuan manusia untuk menerawang kapan berahirnya masa pandemi. Sebagai mahluk yang rentan dan rapuh manusia hanya mampu bertobat, meratap, dan bijak dalam menentukan kebutuhannya. Bertobat berarti kembali kepada pangkuan sang Bapa. Meninggalkan keduniawian dan mengumpulkan harta sorgawi. Meratap berarti menyadari kelemahan dan menyadari kebutuhan pada pertolongan Tuhan dan sesama. Meratap berarti meningkatkan spiritualitas indivual mapan. Spiritual mapan akan mewujud dalam spiritualitas relasi Trinitatis.

Jika Allah yang berempati dengan dunia yang dilanda penderitaan, maka kemahakasihan Allah melalui Yesus sudah jelas tergambar jelas di dalam Injil Kanonik. Ketika Yesus melihat mereka yang menderita, tertindas, sakit, dan papa, Ia langsung tergerak oleh belas kasih yang artinya hati tergerak atas realitas penderitaan orang lain. Jika kemahakasihan Allah didominasi oleh-Nya, maka kerapuhan adalah jati diri manusia. 
Dari kerapuhan manusia dapat melihat sebagai kebajikan bagi manusia untuk saling mencintai. Dalam kerapuhan kita mengambil bagian dalam interaksi dan tanggung jawab bersama. Jadi, menjadi kebal (tidak mengakui kerapuhannya) berarti bahwa sesorang tidak peduli, tidak bertanggung jawab, tidak terbuka dan tidak dapat didekati oleh kasih karunia Allah. Dalam kasih menyahabat, kebal dinilai sebagai penyangkalan terhadap kodrat manusia. Menurut Marianne Moyaret manusia hari ini sedang mengidealkan kekebalan. Manusia ingin terlihat kuat, mandiri, dan merasa penting (Moyaert, 2012). Faktanya, tidak ada manusia yang kebal virus walaupun sudah di vaksin dua kali. Kerentanan memang bisa membuat kita menderita dan kehilangan. Namun, mereka yang sadar akan kerapuhanlah yang mampu benar-benar jatuh cinta, belajar dari orang lain, dan bersukacita serta bersyukur disamping sahabat-sahabatnya. Kerapuhan dalam persabatan harus didasarkan pada subjek yang setara dalam mutualitas.

Perikoresi telah memiliki posisi penting dalam pemahaman gereja terkait sifat ilahi di dalam dirinya sendiri, dalam trinitarianisme, dan sifat manusia dalam Kristologi (Otto, 2001). Perichoresis tergambar dalam relasi yang terjalin dalam Allah Tritunggal, Bapa, Anak, dan Roh. Ketiga Pribadi dalam dalam Trinitas adalah setara, mutual, dan selalu menjalankan eksistensi dalam kebersamaan dan bukan hierarkis (Meeks, 2000, p. 114). Perichoresis yang dimediasi Allah kepada manusia melalui Yesus adalah kehidupan oleh Roh yang memberi harapan pada situasi keputus-asaan, dalam kebingungan, dan di dalam persekutuan ada keterasingan.

Dalam struktur keluarga juga terdapat hubungan hierarkis. Dalam prinsip relasi perichoresis mengutamakan kesetaraan dan kebersamaan, maka hubungan kasih ini harus mengikat erat relasi keluarga. Keluarga sebagai komunitas kecil melakuakn ibadah di rumah memahami eksistensinya sebagai ayah, ibu, dan anak-anak namun tidak hierarkis. Liturgi ibadah keluarga yang mendamba cinta, kehidupan, dan kegembiraan terjadi ketika ada saling berbagi dan saling memiliki satu sama lain dalam sebuah persekutuan keluarga yang intim. Namun, penerapan perichoresis dalam relasi tidak universal. Perichoresis menyangkut apa yang orang lakukan kebersamaan satu sama lain. Ini dapat diperluas untuk mencakup interaksi antar orang-orang dan dunia impersonal (Hohne, 2003).

Orang tua sebagai sahabat bagi anak-anaknya. Demikian juga sebaliknya anakanak menjadi sahabat bagi ke dua orang tuanya. Persahabatan dalam keluarga kristen tidak identik dengan gerontarki atau patriarki (orang dewasa sebagi pemimpin, biasanya laki-laki). Melalui philiarki (persahabatan) menolak klaim diri sebagai kyriarchy dan subordinasi orang lain dalam piramida kekuasaan hierarkis. Ketika sebuah keluarga memiliki jiwa sahabat; ketakutan, kehampaan, dan jarak menjadi hilang. Jiwa persabatan terjalin dalam hubungan memberi dan menerima cinta. Ada dorongan kepenuhan dan keintiman tanpa dibatasi jarak usia. Orang tua yang menyahabat menata kembali masa depan keluarga. Persahabatan kristiani selalu melibatkan pengambilan resiko. Ramah terhadap yang lain tentunya menciptakan banyak resiko. Warna persahabatan dalam kekristenan adalah keterbukaan terhadap masa depan dan ketidak pastian. Seseorang 
dapat tersakiti tetapi seseorang juga dapat menunjukkan cinta yang lebih besar kepada sahabat-sahabat dengan cara yang tidak terduga.

\section{Rekomendasi untuk Penelitian Lanjutan}

Apakah peribadahan di rumah menghasilkan penindasan model baru bagi perempuan? Bagaimana teologi merespon stigmatisasi terhadap kaum perempuan? Bagaimana model ibadah terbatas di rumah yang memiliki arsitektur teologis feminis sebagai liturgi ibadah? Pertanyaan tersebut sebagai saran topik untuk penelitian lanjutan. Stigma perempuan yang identik dengan urusan dapur bisa sebagai wadah kehadiran Allah. Dapur menawarkan harapan. Dapur manawarkan aksi sepiring makanan. Aksi kaum perempuan di dapur lebih berarti dibanding harta melimpah. Dapur membuka perjumpaan yang melintasi batas. Dapur dapat menjadi wadah saling memberi rasa dan mengeratkan. Ibadah di rumah tentu bersinggungan dengan urusan penataan dapur rumah tangga. Menurut tradisi Israel, sebuah rumah memiliki konstruksi arsitektur teologis. Urusan rumah identik dengan kaum perempuan. Dalam struktur Yudais, perempuan identik dengan dapur. Prinsip ini menjadi stigma bagi kaum perempuan. Saat pandemi pintu rumah tertutup, namun dapur harus terus berproduksi. Tanpa kerelaan dari perempuan di dapur kehidupuan berhenti.

\section{Kesimpulan}

Penatalayanan ibadah terbatas (individual-di rumah) memiliki arah dan ciri khas pada basis teologi ketaatan, persekutuan proflektif sebagai ciri jemaat mula-mua, dan pola ibadah hierarkis ke perikoresis. Hal terpenting diperoleh dari penelitian ini adalah penatalayanan liturgi ibadah di rumah yang menyasar pada komunitas keluarga di rumah. Keluarga di rumah menjadi kontrol hukum bagi dirinya sendiri. Sesama anggota keluarga saling menyalurkan kasih dalam relasi perikoresis bukan hierarkis. Pola ibadah di rumah juga menjadi gambaran dinamisasi persekutuan kekristenan awal abad pertama. Kekristenan awal yang masih mengadopsi pola persekutuan agama Yahudi menjadi cerminan dinamisasi peribadatan. Keluarga menjadi basis pembentukan iman dan pembentukan karakter. Beranjak dari pola ibadah keluarga juga membangun masa depan anak-anak untuk menyadari masa depan ibadah jauh ke depan.

\section{Rujukan}

Adiprasetya, J., \& Sasongko, N. (2019). A compassionate space-making: Toward a trinitarian theology of friendship. Ecumenical Review, 71(1-2), 21-31. https://doi.org/10.1111/erev.12416

Berutu, I., \& Evan Siahaan, H. R. (2020). Menerapkan Kelompok Sel Virtual di Masa Pandemi Covid-19. E-Journal.Sttpaulusmedan.Ac.Id, 3(1), 53-65.

Book, R. (2013). RESOURCE BOOK WCC 10th Assembly. Emanuel, Martasudjita., Pr. (2011). Pengantar Untuk Studi Dan Praksis Liturgi oleh Emanuel, Yogyakarta: Kanisius Retrieved October 19, 2021, from 
https://ebooks.gramedia.com/id/buku/liturgi-pengantar-untuk-studi-danpraksis-liturgi

Fransiskus dkk, W. (2021). Menuju Evolusi Ibadah Kristen di Masa Pandemi Covid-19. Jurnal Teologi Berita Hidup, 3(2), 6. https://doi.org/10.24198/jkrk.v2i2.29126.7

Hohne, D. A. (2003). What Can We Say About Perichoresis? : An historical, exegetical and theological examination of Colin Gunton's use of the concept (Issue June). Newtown, N.S.W.

Höring, P. C. (2013). Koinonia: A Roman Catholic Perspective on a Theological Pattern for Youth Ministry in Church as a Community. Journal of Youth and Theology, 12(1), 46-57. https://doi.org/10.1163/24055093-90000060

Hutahaean, H., Silalahi, B. S., \& Simanjuntak, L. Z. (2020). Spiritualitas Pandemik: Tinjauan Fenomenologi Ibadah Di Rumah. Evangelikal: Jurnal Teologi Injili Dan Pembinaan Warga Jemaat, 4(2), 234. https://doi.org/10.46445/ejti.v4i2.270

Langfan, 0. (2021). Ibadah Online di Masa Pandemi Covid-19: Implementasi Ibrani 12:28. Stella: Jurnal Teologi Dan Pendidikan Kristen, 1(1), 15-18.

Lukuhay, A. S. (2020). Analisis Teologis Mengenai Beribadah di Rumah di Tengah Pandemi Covid-19 di Indonesia. VISIO DEI: Jurnal Teologi Kristen, 2(1), 43-61.

Media, K. C. (2021, July 1). Rincian Aturan Disampaikan Siang Ini, Jokowi: PPKM Darurat Lebih Ketat daripada Sebelumnya. KOMPAS.com. https://nasional.kompas.com/read/2021/07/01/11371671/rincian-aturandisampaikan-siang-ini-jokowi-ppkm-darurat-lebih-ketat

Meeks, M. D. (2000). Trinity, Community and Power: Mapping Trajectories in Wesleyan Theology.

Michel, Virgil. OSB., (2013) The 50 th Anniversary of the Constitution on the Sacred Liturgy. Archdiocese of Chicago.

Mohrlang, R. (1984). Matthew and Paul: A Comparison of Ethical Perspectives. Cambridge University Press; 1st edition.

Moyaert, M. (2012). On vulnerability: Probing the ethical dimensions of comparative theology. Religions, 3(4), 1144-1161. https://doi.org/10.3390/rel3041144

Otto, R. E. (2001). The Use and Abuse of Perichoresis in Recent Theology. Scottish Journal of Theology, 54(3), 366-384. https://doi.org/10.1017/s0036930600051656

Saragih, A., \& Hasugian, J. W. (2020). Model Asuhan Keluarga Kristen di Masa Pandemi Covid-19. Jurnal Teruna Bhakti, 3(1), 1. https://doi.org/10.47131/jtb.v3i1.56

Saragih, E. S. (2019). Pola Mendidik di Sinagoga dalam Tradisi Israel dan Implikasinya pada Pendidikan Kristiani. 12.

Schmemann, Alexander Fr., Worship In A Secular Age.

Siahaan, H. E. R. (2021). Bahasa Roh dan Spiritualitas Perikoresis dalam Peristiwa Pentakosta: Analisis Reinterpretatif Kisah Para Rasul 2: 1-13. 1-13.

Silitonga. (2020). Respon Gereja Atas Pandemik Corona Virus Desease 2019. 2(April), 86111. 
Sim, D. C. (1998a). The Gospel of Matthew and Christian Judaism: The History and Social Setting of The Matthean Community. T\&T Clark.

Sim, D. C. (1998b). The Gospel of Matthew and Christian Judaism: The history and social setting of the Matthean Community. Clark.

Sorongan, T. (n.d.). Alert! WHO Beri Peringatan Terbaru Soal Penyebaran Covid-19. CNBC Indonesia. Retrieved July 29, 2021, from https://www.cnbcindonesia.com/news/20210728205235-4-264447/alert-whoberi-peringatan-terbaru-soal-penyebaran-covid-19

Tupamahu, E. (2013). A Perichoretic Model For Christian Love: A Theological Response to "A Common Word Between Us and You. Indonesian Journal of Theology, 1(1), 67-89.

Wowor, J. P. (2015). Model Pendidikan Kristiani yang Mengupayakan Koinonia dalam Konteks Kemajemukan Agama di Indonesia. Gema Teologi, 39(2), 187-204.

Zega, S. (2020). Refleksi Teologis tentang Makna Ibadah yang Sejati. Voice of HAMI: Jurnal Teologi Dan Pendidikan Agama Kristen, 3(1), 28-38. 